\title{
CHARACTERISTIC OF THE CONTENT OF FUNGI SPORES' AIR SPECTRUM AS POTENTIALLY ALLERGENIC COMPONENT OF BIOAEROSOL
}

Bilous O.S., Rodinkova V.V., Yermishev O.V. ХАРАКТЕРИСТИКА СКЛЛДУ ПОВІТРЯНОГО СПЕКТРА СПОР ГРИБІВ
ЯК ПОТЕНЦЙНО АЛЕРГЕННОГО КОМПОНЕНТА БІОАЕРОЗОЛЮО

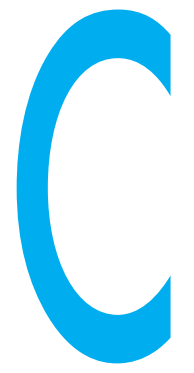

1БІЛОУс О.С., 2РОДІНКОВА В.В., उЕРMІШЕВ O.B.

1Вінницька міська поліклініка № 2

2Вінницький національний медичний університет

ім. М.І. Пирогова,

зДонецький національний університет ім. Василя Стуса, м. Вінниця.

УДК:

533.6.001.8:612.017.3:582.21

\author{
Ключові слова: \\ спори грибів, \\ алергія, повітря, \\ биоаерозоль, \\ аероалергени.
}

пори грибів (СГ) є важливими аероалергенами, практичне значення яких зросло за останні десятиліття. Це пов'язане, 3 одного боку, з загальним збільшенням частоти алергійних захворювань (АЗ), а 3 іншого - зі зростанням кількості імунокомпрометованих індивідуумів, таких як хворі на певні генетичні вади, СНІД або $є$ одержувачами трансплантатів [1].

Спори і фрагменти грибів зустрічаються повсюдно над неполярними районами Землі, особливо над сільськогосподарськими регіонами, і можуть складати до 45\% частинок у біоаерозолі повітря [2]

Найчастіше у надвисоких концентраціях у повітрі визначаються спори Cladosporium та Alternaria. Аскоспори (Ascomycetes) і базидіоспори (Basidiomycetes) також ідентифікуються у великих кількостях. [3], складаючи від 40\% до 100\% загальних грибів, виявлених у повітряному біоаерозолі $[4,5]$.
Тому спори, що містяться у повітрі, регулярно та постійно вдихаються людьми. Було припущено, що СГ, які присутні в атмосфері у високих концентраціях, можуть бути причинними агентами респіраторних хвороб (риніт, астма) у людини. Основна відмінність СГ від інших джерел алергії, наприклад кліща домашнього пилу або пилку, це те, що гриби можуть колонізувати організм людини і здатні пошкодити дихальні шляхи, виробляючи токсини, протеази, ферменти та летючі органічні сполуки, справляючи набагато більший вплив на імунну систему пацієнтів, аніж пилок або інші алергенні джерела [6].

Однак значимість багатьох грибів для алергії залишається важкою для її оцінки і вимагає спеціальних досліджень. Так, було показано, що велика група грибів провокує алергічні реакції негайного типу у чутливих людей, а також негайні та пізньоастматичні реакції з бронхопровокацією. Проте у разі

\begin{abstract}
ХАРАКТЕРИСТИКА СОСТАВА ВОЗДУШНОГО СПЕКТРА СПОР ГРИБОВ КАК ПОТЕНЦИАЛЬНО АЛЛЕРГЕННОГО КОМПОНЕНТА БИОАЭРОЗОЛЯ

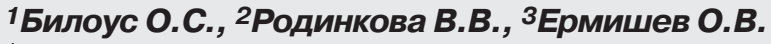
${ }^{1}$ Винницкая городская поликлиника № 2 , ${ }^{2}$ Винницкий национальный медицинский университет им. Н.И. Пирогова,

ЗДонецкий национальный университет им. Васыля Стуса, г. Винница.
\end{abstract}

Споры и фрагменты грибов встречаются повсеместно над неполярными районами Земли, осо бенно над сельскохозяйственными регионами, составляя до 45\% частиц в биоаэрозоле воздуха, и могут вызывать симптомы аллергии. В статье описан спектр спор грибов как потенциальных аэроаллергенов и его часовые изменения в атмосферном воздухе города Винница. Материалы и методы. Исследование, проведенное в 2009-2014 годах волюметрическим методом, выявило в атмосфере более 30 категорий спор грибов, многие из которых имеют клинически доказанные свойства вызывать сезонную аллергию.

Результаты. Показано доминирование спор рода Cladosporium в воздушном биоаэрозоле, что соответствует результатам наблюдения в большин- стве точек мира. В целом в атмосферном воздухе доминировали представители отдела аскомицетовых грибов (Ascomycota), а также наблюдались представители базидиомицетовых грибов (Basidiomycota) и псевдогрибов (Oomycota). В частности, в перечень лидеров по показателю годового спорового индекса входили споры Alternaria, Ascospora, Cladosporium, Coprinus, Didymella, Epicoccum, Ganoderma, Leptosphaeria, споры порядков Uredinales та Ustilaginales. Больше всего СГ регистрировалось в атмосферном воздухе в период с июня по октябрь с четко очерченными подъемами концентрации (в основном за счет спор Cladosporium) в июне и июле. Пиками в июле характеризовались Alternaria и Ascospores. В осенние месяцы отмечалась более высокая концентрация спор в воздухе, чем в весенние месяцы и в первой половине июня.

Выводы. Данные по контенту спор атмосферного воздуха для длительного периода наблюдения получены для Украины впервые, что позволит улучшить диагностику и профилактику сезонной аллергии в нашей стране.

Ключевые слова: споры грибов, аллергия, воздух, биоаэрозоль, аэроаллергены. 
CHARACTERISTIC OF THE CONTENT OF FUNGI SPORES' AIR SPECTRUM AS POTENTIALLY ALLERGENIC COMPONENT OF BIOAEROSOL

${ }^{1}$ Bilous O.S., ${ }^{2}$ Rodinkova V.V., ${ }^{3}$ Yermishev O.V.

${ }^{1}$ Vinnytsia City Hospital № 2,

2 Vinnytsia National M.I. Pyrohov Medical University, ${ }^{3}$ Donetsk National Vasyl Stus University, Vinnytsia.

Fungi spores and fragments occur everywhere over non-polar regions of the Earth, especially over agricultural regions, make up to $45 \%$ of particles in the air bioaerosol and can cause symptoms of allergy. In the article, we described the spectrum of fungi spores as the potential aeroallergens and its temporal changes in the ambient air of the city of Vinnytsia.

Materials and methods. We carried out the study with the help of volumetric method in 2009-2014, we detected more than 30 categories of spores of fungi in the atmosphere, many of them had clinically proved features to cause seasonal allergy.

Results. Dominance of Cladosporium spores is demonstrated in the air bioaerosol, it conforms to the results of the observation in the majority of points throughout the world. In general, the representatives of the ascomycetes fungi (Ascomycota) dominated in ambient air, as well as the representatives of Basidiomycetes and pseudofungi (Oomycota). In particular, the list of the leaders by the indicator of the annual spore index consisted of Alternaria, Ascospora, Cladosporium, Coprinus, Didymella, Epicoccum,

Ganoderma, Leptosphaeria, spores of Uredinales and Ustilaginales.

Most of fungi spores were recorded in ambient air from June to October with clearly defined increases in concentration, basically due to Cladosporium spores in June and July. Peaks in July were characterized by Alternaria and Ascospores. A larger concentration of spores was observed in ambient air in autumn months than in spring months and in the first half of June.

Conclusions. Findings on the spore content of ambient air for a long period of observation were obtained for Ukraine for the first time. The result will improve the diagnosis and prevention of seasonal allergy in our country.

Keywords: fungi spores, allergy, air, bioaerosol, aeroallergens. спроб пов'язати симптоми 3 безпосереднім впливом грибкового матеріалу на організм людини виникають невизначеності. Ця проблема зумовлена природою та особливостями поширення грибів у довкіллі [7].

Кількість видів мікроміцетів визначається приблизно у 100000-200000 видів. Щорічно описується до 1500 нових видів грибів. За даними літератури, реальне значення у клінічній практиці нині мають близько 100 родів спор грибів (СГ). Саме гриби у $21.2 \%$ випадків $€$ етіологічними чинниками алергійних захворювань органів дихання [8].

Так, у період проведення жнив, провідне значення мають гриби 3 родів Alternaria, Cladosporium, Epicoccum, що перебувають на зернових культурах, під час зберігання зібраного зерна - представники родів Aspergillus, Penicillium, Mucor, Rhizopus [9].

Дослідження, проведені у Новій Зеландії, показали, що спори таких грибів, як Alternariatenuis, Cladosporiumcladosporoides, Helminthosporiummaydista Epicoccumnigrum можуть викликати гострі напади астми [10].

Епідеміологічні дослідження фунгальної алергії в Європі виявили, що найбільш важливими джерелами грибкових аероалергенів $€$ Alternaria та Cladosporium [11]. Це - найважливіші $з$ практичної точки зору роди аскоміцетових грибів, спори яких провокують у жителів континенту хвороби дихальних шляхів, такі як астма, екзема, риніт та хронічний синусит [12].

Поширеність респіраторної алергії до грибів оцінюється у межах 20-30\% від числа атопічних (схильних до алергії) осіб, або до 6\% загального населення [13]. Деякі дослідники відзначають, що сенсибілізація до СГ реєструється у $80 \%$ пацієнтів з астмою [6].

Оскільки ізольованого "сезону грибкової цвілі" за аналогією з сезоном пилкування рослин не буває, визначення рівня захворюваності протягом року може надавати тільки обмежену допомогу у діагностиці алергії до грибів. Важливим тут $€$ контроль спектра СГ та їх концентрацій в оточуючому пацієнта середовищі, адже симптоми фунгальної алергії часто

\section{Усереднена зміна концентрацій сг основних категор зареєстрованих в атмосферному повітрі м. Вінниця у 2009-2014 роках}

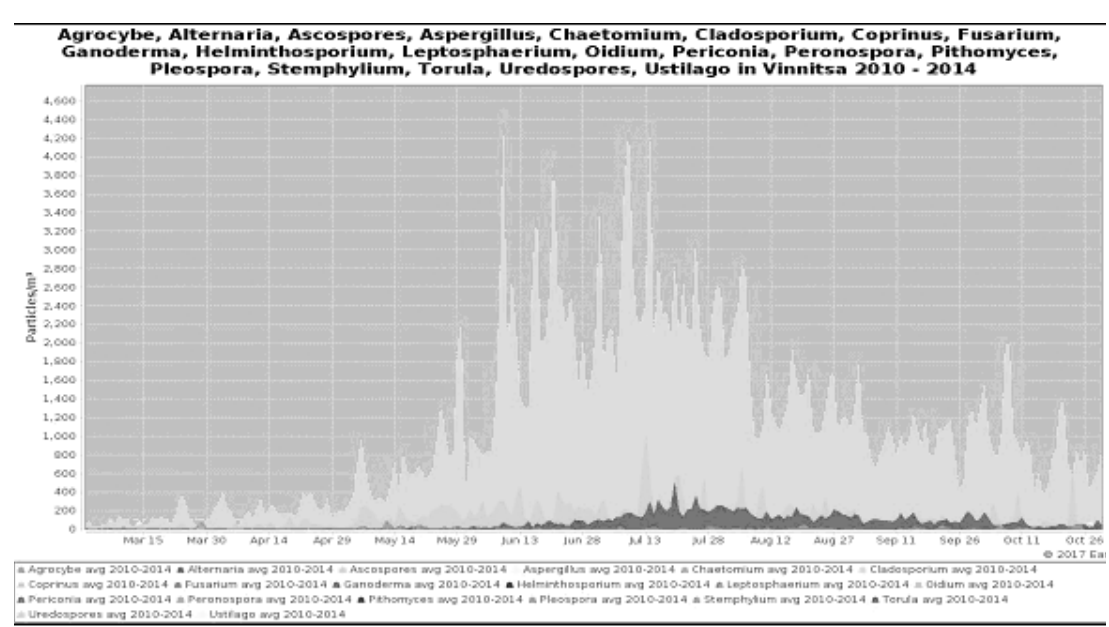


Після експонування зразки фарбували сумішшю желатину, гліцерину та фенолу з додаванням невеликої кількості основного фуксину - індикатора, що слугує для диференційованого забарвлення рослинного матеріалу. Підготовлені зразки читали при збільшенні 400X або 1000Х за трьома горизонтальними лініями у 2009-2011 роках і за 12 вертикальними лініями - у 2012-2014 роках.

Результати. За період моніторингу 2009-2014 років в атмосферному повітрі міста Вінниця було визначено понад 30 представників різних таксономічних категорій спор грибів, 29 з яких було взято до подальшого аналізу.

Це представники грибів відділу Ascomycota порядку Erysiphales, родів Alternaria (ALTE), Aspergillu S(ASPE), Botrytis (BOTR), Cercospora (CERC), Chaetomium (CHAE), Cladosporium (CLAD), Curvularia (CURV), Didymella (DIDY), Epicoccum (EPIC), Fusarium (FUSA), Drechslera/Helminthosporium (HELM), Leptosphaeria (LEPT), Oidium (OIDI), Periconia (PERI), Pleospora (PLEO), Pithomyces (PITH), Polytrinchium (POLT), Stemphylium (STEM), Torula (TORU) та окремо - неідентифіковані спори представників класу Ascomycota (ASCO), так звані аскоспори.

Наступну категорію склали спори базидіоміцетових грибів відділу Basidiomycota - окремо класів Uredibales (URED), Ustilaginales (USTI) та родів Agrocybe (AGRO), Coprinus (COPR), Ganoderma (GANO), Puccinia (PUCC). Неідентифіковані базидіоспори належали до категорії Basodiospora (BASI). Клас Ооміцетів (несправжніх грибів) був представлений родом Peronospora (PERO).

Найбільше СГ реєструвалось в атмосферному повітрі у період 3 червня по жовтень 3 чітко окресленими підйомами концентрації, переважно за рахунок СГ Cladosporium у червні та липні. Піками у липні характеризувались і СГ Alternaria та Ascospores (рис.).

Проведено ретельний аналіз термінів та інтенсивності споруляції усіх представників кожної 3 названих таксономічних груп грибів в окремі роки, а також визначені зміни цих термінів у часі.
Було проведено порівняння термінів початку, пікових періодів та часу закінчення СП для окремих груп грибів, визначено їхній внесок в інтенсивність спорового дощу в атмосферному повітрі міста Вінниця протягом сезону та за місяцями.

На основі отриманих даних зроблено висновки щодо спектра СГ в атмосферному повітрі Вінниці за період спостереження, які лягли в основу сезонних алергопрогнозів, що надаються населенню на щотижневій основі (табл.).

Якісний та кількісний розподіл СГ різних таксономічних одиниць у часі.

Для визначення внеску кожного $з$ компонентів у споровий дощ атмосферного повітря міста Вінниця та загальних характеристик окремих сезонів спор (СС) застосовано інструменти описової статистики EAN, які дали змогу визначити й терміни старту, закінчення та пікові концентрації СГ під час CC. Визначення спорового індексу (Cl) суми зібраних за сезон спор окремої категорії, а також середнього арифметичного (М) та стандартного відхилення (б) проводилось у програмі Excel.

Результати аналізу показали, що найбільшою в усі роки спостереження у споровому дощі була питома вага спор аскоміцетових грибів Cladosporium. Ï̈̈ частка коливалась між найбільшим значенням у $76 \%$ від сумарного $\mathrm{Cl}$ усіх категорій СГ у 2011 році та найменшим значенням у $56 \%$ у 2010 році. В усі інші роки частка Cladosporium коливалась у межах 64-67\%.

Для цієї ж категорії були визначені й найбільші серед усіх рядів даних за кожен рік середні значення та значення стандартного відхилення. Значення середньосезонної концентрації СГ Cladosporium перевищувало 1000 спор/м³ в усі роки спостережень, крім 2013 та 2014.

Друге місце за внеском в інтенсивність спорового дощу над Вінницею посідали спори Coprinus та неідентифіковані спори аскоміцетових грибів, об'єднані у категорію Ascospora, у 2009, 2011 та у 2013 роках з частками $6 \%, 4 \%$ та $9 \%$ відповідно. Ascospora була другою за внеском у споровий дощ у 2010, 2012 та 2014 роках. Питома вага цих спор у відбору зразків атмосферного повітря [19]. 
названі роки становила 8\%, $12 \%$ та $11 \%$ відповідно. У 2009 , 2011 та 2013 роках Ascospora була на третій позиції за інтенсивністю пилкового дощу, чергуючись 2010 року з Coprinus, у 2012 та 2014 роках - 3 Alternaria. Третя позиція у споровому спектрі з часткою по $6 \%$ у кожен 3 названих років була найвищою для відомої своєю алергенністю Alternaria.
В інші роки вона посідала сьому (2009, 2010), шосту (2011) та четверту (2013) позиції у споровому спектрі Вінниці.

Інша спора, алергенність якої доведено [20], Leptosphaeria, посідала з 5 по 9 сходинки спорового спектра у 2009-2014 роках. Ї̈̈ частка коливалась від 1\% до 7\% (табл.).

Загалом перша десятка лідерів за масивністю споруляції мала сталий склад в усі роки спостереження. До переліку лідерів входили Alternaria, Ascospora, Cladosporium, Coprinus, Didymella, Epicoccum, Ganoderma, Leptosphaeria, Uredinales, Ustilaginales. y 2010 році, замінивши Epicoccum, до першої десятки увійшла група спор Dreschlera/Helminthosporium. у 2011 році замість Uredinales у десятці лідерів 3'я-

Внесок різних представників Сг у загальний споровий дощ м. Вінниці у 2009-2014 роках

\begin{tabular}{|c|c|c|c|c|c|c|c|c|c|c|c|c|}
\hline & $\begin{array}{c}2009, \% \\
\text { від Сl }\end{array}$ & $\mathrm{M} \pm \mathrm{m}$ & $\begin{array}{c}2010, \% \\
\text { від Cl }\end{array}$ & $M \pm m$ & $\begin{array}{c}2011, \% \\
\text { від Cl }\end{array}$ & $\mathrm{M} \pm \mathrm{m}$ & \begin{tabular}{|c|}
$2012, \%$ \\
від Сl
\end{tabular} & $\mathrm{M} \pm \mathrm{m}$ & \begin{tabular}{|c|}
$2013, \%$ \\
від Сl
\end{tabular} & $\mathrm{M} \pm \mathrm{m}$ & $\begin{array}{c}2014, \% \\
\text { від Сl }\end{array}$ & $\mathrm{M} \pm \mathrm{m}$ \\
\hline AGRO & $\begin{array}{c}1,86 \\
<<1 \%\end{array}$ & & $\begin{array}{c}3052 \\
1 \%\end{array}$ & & $\begin{array}{c}825 \\
<<1 \%\end{array}$ & & $\begin{array}{c}1652,83 \\
<1 \%\end{array}$ & & $\begin{array}{c}447,40 \\
<<1 \%\end{array}$ & & $\begin{array}{l}200,65 \\
<<1 \%\end{array}$ & \\
\hline ASCO & $\begin{array}{c}25518 \\
6 \%\end{array}$ & $\begin{array}{l}128,88 \pm \\
248,534\end{array}$ & $\begin{array}{c}44649 \\
8 \%\end{array}$ & & $\begin{array}{c}23725,01 \\
4 \%\end{array}$ & & $\begin{array}{c}38758,81 \\
9 \%\end{array}$ & & $\begin{array}{c}27243,43 \\
9 \%\end{array}$ & $\begin{array}{l}113,99 \pm \\
242,630\end{array}$ & $\begin{array}{c}22312,87 \\
11 \%\end{array}$ & $\begin{array}{l}104,27 \pm \\
138,301\end{array}$ \\
\hline ALTE & $\begin{array}{c}14173,4 \\
3 \%\end{array}$ & $\begin{array}{l}71,58 \pm \\
68,927\end{array}$ & $\begin{array}{c}23976 \\
4 \%\end{array}$ & $\begin{array}{c}97,86 \pm \\
150,950\end{array}$ & $\begin{array}{c}18557 \\
3 \%\end{array}$ & \begin{tabular}{|c|}
$75,74 \pm$ \\
120,683
\end{tabular} & $\begin{array}{l}23200 \\
02,6 \%\end{array}$ & & \begin{tabular}{|c|}
14716,25 \\
$5 \%$
\end{tabular} & $\begin{array}{l}60,07 \pm \\
84,256\end{array}$ & $\begin{array}{c}10711,91 \\
6 \%\end{array}$ & $\begin{array}{l}43,72 \pm \\
50,934\end{array}$ \\
\hline ASPE & & & $\begin{array}{l}858 \\
<1 \%\end{array}$ & $\begin{array}{l}3,5 \\
14,8\end{array}$ & $\begin{array}{c}18 \\
<<1 \%\end{array}$ & & $\begin{array}{c}1978 \\
16,<1 \%\end{array}$ & & $\begin{array}{c}1156,82 \\
<1 \%\end{array}$ & $\begin{array}{l}3 \pm \\
08\end{array}$ & $\begin{array}{c}636,38 \\
<<1 \%\end{array}$ & $\begin{array}{l}79 \pm \\
964\end{array}$ \\
\hline BOTR & $\begin{array}{l}687 \\
<1 \%\end{array}$ & $\begin{array}{l}3,47 \pm \\
8,264\end{array}$ & $\begin{array}{l}579 \\
<1 \%\end{array}$ & & $\begin{array}{c}4361 \\
1 \%\end{array}$ & $\begin{array}{l}17,80 \pm \\
45,789\end{array}$ & $\begin{array}{l}34,58 \\
<<1 \%\end{array}$ & & & & & \\
\hline $\mathrm{CHAE}$ & $\begin{array}{c}6 \\
<1 \%\end{array}$ & & $\begin{array}{l}1185 \\
<1 \%\end{array}$ & & $\begin{array}{c}8 \\
<<1 \%\end{array}$ & & $\begin{array}{c}426,07 \\
<<1 \%\end{array}$ & & $\begin{array}{l}99,41 \\
<<1 \%\end{array}$ & & $\begin{array}{l}29,64 \\
<<1 \%\end{array}$ & $\begin{array}{l}2,12 \pm \\
3,313\end{array}$ \\
\hline CLAD & $\begin{array}{c}283319,3 \\
67 \%\end{array}$ & $\begin{array}{c}1430,91 \pm \\
1264,884\end{array}$ & $\begin{array}{c}304517 \\
56 \%\end{array}$ & $\begin{array}{l}1242,93 \pm \\
1361,837\end{array}$ & $\begin{array}{c}494932 \\
76 \%\end{array}$ & \begin{tabular}{|l|}
2020,13 \\
$\pm 2493,6$
\end{tabular} & $\begin{array}{c}262714 \\
6,64 \%\end{array}$ & $\begin{array}{l}1072,30 \pm \\
1057,699\end{array}$ & $\begin{array}{c}204803,6 \\
65 \%\end{array}$ & $\begin{array}{c}835,93 \pm \\
1013,333\end{array}$ & $\begin{array}{c}128480,4 \\
67 \%\end{array}$ & $\begin{array}{l}526,56 \pm \\
596,128\end{array}$ \\
\hline COPR & $\begin{array}{c}33936 \\
8 \%\end{array}$ & $\begin{array}{l}0 \pm \\
78\end{array}$ & $\begin{array}{c}38477 \\
7 \%\end{array}$ & & $\begin{array}{c}26658,01 \\
4 \%\end{array}$ & & $\begin{array}{l}23114, \\
27,6 \%\end{array}$ & & \begin{tabular}{|c|}
28369,16 \\
$9 \%$
\end{tabular} & $\begin{array}{l}127,22 \pm \\
177,687\end{array}$ & $\begin{array}{c}10434,96 \\
5 \%\end{array}$ & 336 \\
\hline CURV & & & $\begin{array}{l}536 \\
<1 \%\end{array}$ & $\begin{array}{c}2,19 \pm 4 \\
300\end{array}$ & $\begin{array}{l}256 \\
<1 \%\end{array}$ & & $\begin{array}{c}125,99 \\
<<1 \%\end{array}$ & & $\begin{array}{l}16,67 \\
<<1 \%\end{array}$ & & $\begin{array}{c}5,57 \\
<<1 \%\end{array}$ & \\
\hline DIDY & $\begin{array}{c}23464 \\
6 \%\end{array}$ & $\begin{array}{l}118,51 \pm \\
309,441\end{array}$ & $\begin{array}{c}17443 \\
3 \%\end{array}$ & $\begin{array}{c}71,20 \pm \\
219,288\end{array}$ & $\begin{array}{c}12850 \\
2 \%\end{array}$ & \begin{tabular}{|c|}
$52,45 \pm$ \\
168,631
\end{tabular} & $\begin{array}{c}8009 \\
71,2 \%\end{array}$ & & \begin{tabular}{|c|}
2523,85 \\
$1 \%$
\end{tabular} & $\begin{array}{l}34,58 \pm \\
38,481\end{array}$ & $\begin{array}{c}1141,91 \\
1 \%\end{array}$ & $\begin{array}{l}20,04 \pm \\
27,120\end{array}$ \\
\hline EPIC & $\begin{array}{c}3184 \\
1 \%\end{array}$ & $\begin{array}{l}16,08 \pm \\
17,241\end{array}$ & $\begin{array}{c}4530 \\
1 \%\end{array}$ & & $\begin{array}{c}4459 \\
1 \%\end{array}$ & & \begin{tabular}{|c|}
3507 \\
$42,1 \%$
\end{tabular} & & $\mid \begin{array}{c}5036,27 \\
2 \%\end{array}$ & $\begin{array}{c}35,72 \pm \\
113,587\end{array}$ & \begin{tabular}{|c|}
207,11 \\
$<<1 \%$
\end{tabular} & \\
\hline ZYS & $\begin{array}{l}1420 \\
<1 \%\end{array}$ & $\begin{array}{r}7,1 \\
10,5\end{array}$ & $\begin{array}{l}358 \\
<1 \%\end{array}$ & & & & & & & & $\begin{array}{l}30,25 \\
<<1 \%\end{array}$ & \\
\hline FUSA & & & & & $\begin{array}{l}3064 \\
<1 \% \\
\end{array}$ & & $\begin{array}{l}2883 \\
72,1 \% \\
\end{array}$ & & $\begin{array}{c}1844,28 \\
1 \%\end{array}$ & $\begin{array}{l}15,50 \pm \\
25,519\end{array}$ & $\begin{array}{c}1962,5 \\
1 \%\end{array}$ & $\begin{array}{l}21,81 \pm \\
25,098\end{array}$ \\
\hline ANO & $\begin{array}{l}1851 \\
<1 \%\end{array}$ & $\begin{array}{c}9,35 \pm \\
17,046\end{array}$ & $\begin{array}{c}4736 \\
1 \%\end{array}$ & $\begin{array}{l}19, \\
27,\end{array}$ & $\begin{array}{c}4825 \\
1 \%\end{array}$ & & $\begin{array}{c}6520 \\
38,2 \%\end{array}$ & & \begin{tabular}{|c|}
3619,95 \\
$1 \%$
\end{tabular} & $\begin{array}{l}24,97 \pm \\
26,019\end{array}$ & \begin{tabular}{|c|}
1396,19 \\
$1 \%$
\end{tabular} & $\begin{array}{l}11,54 \pm \\
12,830\end{array}$ \\
\hline ELM & $\begin{array}{l}981 \\
<1 \%\end{array}$ & & $\begin{array}{c}4835 \\
1 \%\end{array}$ & & $\begin{array}{l}2876 \\
<1 \%\end{array}$ & & $\begin{array}{c}166,21 \\
<<1 \%\end{array}$ & $\begin{array}{l}2,28 \pm 1 \\
696\end{array}$ & $\begin{array}{l}75,98 \\
<<1 \%\end{array}$ & & $\begin{array}{l}54,96 \\
<<1 \%\end{array}$ & \\
\hline LEPT & $\begin{array}{c}12781 \\
3 \%\end{array}$ & \begin{tabular}{|c|}
$64,55 \pm$ \\
152,926 \\
\end{tabular} & $\begin{array}{c}36975 \\
7 \%\end{array}$ & \begin{tabular}{|l|}
$150,92 \pm$ \\
239,386
\end{tabular} & $\begin{array}{c}12521 \\
2 \%\end{array}$ & $\begin{array}{l}1 \pm \\
82\end{array}$ & \begin{tabular}{|l|}
12162 \\
$63,3 \%$ \\
\end{tabular} & $\begin{array}{c}62,37 \pm \\
108,452\end{array}$ & \begin{tabular}{|c|}
8268,22 \\
$3 \%$
\end{tabular} & $\begin{array}{l}67,77 \pm \\
81,123\end{array}$ & $\begin{array}{c}1884,97 \\
1 \%\end{array}$ & $\begin{array}{l}39,27 \pm \\
70,788\end{array}$ \\
\hline MYXO & $\begin{array}{l}320 \\
<1 \%\end{array}$ & $\begin{array}{c}1,62 \pm \\
4,753213 \\
\end{array}$ & $\begin{array}{l}180 \\
<1 \%\end{array}$ & & & & $\begin{array}{c}378,56 \\
<<1 \%\end{array}$ & & $\begin{array}{l}52,45 \\
<<1 \%\end{array}$ & & & \\
\hline OIDI & & & $\begin{array}{c}3151 \\
1 \% \\
\end{array}$ & & $\begin{array}{l}2275 \\
<1 \%\end{array}$ & 02 & $\begin{array}{c}591,46 \\
<<1 \%\end{array}$ & & $\begin{array}{c}318,54 \\
<<1 \%\end{array}$ & & \begin{tabular}{|c|}
527,41 \\
$1 \%$
\end{tabular} & $\begin{array}{l}76 \pm \\
909 \\
\end{array}$ \\
\hline TH & & & $\begin{array}{l}958 \\
<1 \%\end{array}$ & & $\begin{array}{c}392 \\
<<1 \%\end{array}$ & & $\begin{array}{c}313,94 \\
<<1 \%\end{array}$ & & $\begin{array}{c}246,38 \\
<<1 \%\end{array}$ & & $\begin{array}{l}95,71 \\
<<1 \%\end{array}$ & \\
\hline $\mathrm{E} \mathrm{I}$ & & & $\begin{array}{c}12997 \\
2 \%\end{array}$ & & $\begin{array}{c}18640,01 \\
3 \%\end{array}$ & & \begin{tabular}{|l|}
3041 \\
$28,1 \%$ \\
\end{tabular} & & \begin{tabular}{|c|}
1839,31 \\
$1 \%$
\end{tabular} & $\begin{array}{l}14,83 \pm \\
28,817\end{array}$ & $\begin{array}{c}1613 \\
29,1 \%\end{array}$ & $\begin{array}{l}12,51 \pm \\
16,003\end{array}$ \\
\hline RO & & & $\begin{array}{c}3375 \\
1 \%\end{array}$ & & $\begin{array}{l}1667 \\
<1 \%\end{array}$ & & $\begin{array}{c}1172 \\
41,<1 \%\end{array}$ & & \begin{tabular}{c|}
670,94 \\
$<1 \%$
\end{tabular} & & $\begin{array}{c}512,72 \\
<<1 \%\end{array}$ & $\begin{array}{l}4,46 \pm \\
4,782\end{array}$ \\
\hline EC & $\begin{array}{l}1405 \\
<1 \%\end{array}$ & $\begin{array}{l}7,10 \pm \\
9,271\end{array}$ & $\begin{array}{c}3150 \\
1 \%\end{array}$ & & $\begin{array}{l}1825 \\
<1 \%\end{array}$ & & $\begin{array}{c}957,12 \\
<1 \%\end{array}$ & & & & $\begin{array}{c}327,32 \\
<<1 \%\end{array}$ & $\begin{array}{l}2,82 \pm \\
3,590\end{array}$ \\
\hline PUCC & & & $\begin{array}{l}573 \\
<1 \% \\
\end{array}$ & $\begin{array}{l}2,34 \pm \\
7,374\end{array}$ & $\begin{array}{c}213 \\
<<1 \%\end{array}$ & $\begin{array}{l}0,87 \pm \\
2,454\end{array}$ & \begin{tabular}{|c|}
481,73 \\
$<<1 \%$
\end{tabular} & & \begin{tabular}{c|}
543,79 \\
$<1 \%$
\end{tabular} & $\begin{array}{l}6,32 \pm \\
9,754\end{array}$ & $\begin{array}{l}579,01 \\
<<1 \%\end{array}$ & $\begin{array}{c}6,43 \pm \\
12,135\end{array}$ \\
\hline $\mathrm{S}$ & $\begin{array}{l}930 \\
<1 \% \\
\end{array}$ & $\begin{array}{l}4,70 \pm \\
6,681\end{array}$ & $\begin{array}{l}2498 \\
<1 \%\end{array}$ & $\begin{array}{c}10,20 \pm 3 \\
1,221\end{array}$ & $\begin{array}{l}1262 \\
<1 \%\end{array}$ & $\begin{array}{c}5,15 \pm 7 \\
883\end{array}$ & $\begin{array}{c}372,08 \\
<<1 \%\end{array}$ & $2,27 \pm 2,0$ & $\begin{array}{c}315,62 \\
<<1 \%\end{array}$ & $\begin{array}{c}2,72 \pm 2 \\
459\end{array}$ & $\begin{array}{c}361,28 \\
<<1 \%\end{array}$ & $\begin{array}{l}3,20 \pm \\
7,944\end{array}$ \\
\hline TORU & $\begin{array}{l}433 \\
<1 \%\end{array}$ & $\begin{array}{l}2,19 \pm \\
4,551\end{array}$ & $\begin{array}{l}1625 \\
<1 \%\end{array}$ & & $\begin{array}{l}1421 \\
<1 \%\end{array}$ & $\begin{array}{c}5,8 \pm \\
6,537\end{array}$ & $\begin{array}{c}623,89 \\
<<1 \%\end{array}$ & $\begin{array}{l}3,20 \pm \\
3,263\end{array}$ & $\begin{array}{c}347,69 \\
<<1 \%\end{array}$ & $\begin{array}{l}2,67 \pm \\
2,774\end{array}$ & $\begin{array}{l}371,09 \\
<<1 \%\end{array}$ & $\begin{array}{l}2,83 \pm \\
8,470\end{array}$ \\
\hline URED & $\begin{array}{c}4303 \\
1 \%\end{array}$ & $\begin{array}{l}21,73 \pm \\
63,381\end{array}$ & $\begin{array}{l}7615 \\
2 \%\end{array}$ & & $\begin{array}{c}3331 \\
1 \%\end{array}$ & $\begin{array}{l}13,60 \pm \\
18,806\end{array}$ & \begin{tabular}{|c|}
3879 \\
$88,1 \%$
\end{tabular} & $\begin{array}{l}17,32 \pm \\
19,021\end{array}$ & \begin{tabular}{|c|}
3846,58 \\
$1 \%$
\end{tabular} & $\begin{array}{l}19,93 \pm \\
24,317\end{array}$ & $\begin{array}{c}2420,35 \\
1 \%\end{array}$ & $\begin{array}{l}15,82 \pm \\
16,530\end{array}$ \\
\hline USTI & $\begin{array}{c}16732 \\
4 \%\end{array}$ & \begin{tabular}{|c|}
$84,51 \pm$ \\
149,102
\end{tabular} & $\begin{array}{c}24839 \\
5 \%\end{array}$ & \begin{tabular}{|l|}
$101,38 \pm$ \\
125,938
\end{tabular} & $\begin{array}{c}14414 \\
2 \%\end{array}$ & $\begin{array}{l}58,83 \pm \\
69,735\end{array}$ & \begin{tabular}{|l|}
15692, \\
$34,4 \%$
\end{tabular} & $\begin{array}{l}67,35 \pm \\
58,520\end{array}$ & \begin{tabular}{|c|}
10421,15 \\
$3 \%$
\end{tabular} & $\begin{array}{l}43,97 \pm \\
45,069\end{array}$ & $\begin{array}{c}232,21 \\
3 \%\end{array}$ & $\begin{array}{l}24,34 \pm \\
23,469\end{array}$ \\
\hline
\end{tabular}


Серед них переважали представники відділу аскоміцетових грибів (Ascomycota), а також спостерігалися представники базидіоміцетових (Basidiomycota) та несправжніх грибів (Oomycota).

Найбільше СГ реєструвалось в атмосферному повітрі у період з червня по жовтень 3 чітко окресленими підйомами концентрації, в основному за рахунок СГ Cladosporium, у червні та липні.

Піками у липні характеризу-

вилася Periconia, а у 2014 році, окрім Periconia, серед найперших за інтенсивністю спорового дощу були Fusarium та Oidium. Вони замінили тут Didymella, Epicoccum та Ganoderma.

Epicoccum, також відомий своєю алергенністю, не увійшовши до десятки СГ з найбільшим внеском до спорового дощу у 2010 та 2014 роках, посів дванадцяту та дев'ятнадцяту сходинки відповідно 3 часткою близько $1 \%$.

Звичний для аеробіологічних зразків Stemphylium, алергени якого мають перехресні реакції з алергенами Alternaria, вважаються другим за важливістю споровим алергеном після Alternariay США [21]. Він в усі роки спостереження виявлявся у другій десятці СГ, розташованих за зменшенням величини внеску у споровий дощ в атмосферному повітрі міста Вінниця. Його частка завжди була меншою за $1 \%$

Pleospora, яка $€$ однією із статевих стадій розмноження анаморфного (безстатева спора) Stemphylium [1], посідала з 12 по 18 сходинку у споровому спектрі з часткою 1\% та менше.

Стабільні 16-18 позиції у спороспектрі в усі роки спостереження мала Torula, яка останнім часом слугує харчовою добавкою, але також може викликати алергію у чутливих до СГ осіб [22].

Одними 3 найменш інтенсивних споропродуцентів, СГ яких реєструвались в атмосферному повітрі Вінниці, були Chaetomium, Aspergillus, Curvularia, Erysiphales й Myxomycota (табл.).

Таким чином, у повітрі Вінниці у 2009-2014 роках зареєстровано понад 30 категорій спор грибів, багато 3 яких мають доведену клінічно здатність викликати сезонну алергію. валися і СГ Alternaria та Ascospores.

Загалом осінні місяці мали більш високі концентрації СГ у повітрі, аніж весняні та перша половина червня.

У чотири із шести років спостереження (2009-2011 та 2013 роки) найбільший внесок у споровий дощ зроблено СГ Cladosporium, Coprinus та Ascospora. У 2012 та 2014 роках замість Coprinus третю позицію посіла Alternaria.

Найбільшою в усі роки спостереження у споровому дощі була питома вага спор аскоміцетових грибів Cladosporium. Ïï частка коливалася між найбільшим значенням у 76\% від сумарного Сl усіх категорій СГ у 2011 році та найменшим значенням у $56 \%$ у 2010 році.

\section{Висновки}

Показано домінування у повітряному біоаерозолі спор роду Cladosporium, що відповідає результатам спостереження у більшості точок світу. Загалом в атмосферному повітрі домінували представники відділу аскоміцетових грибів (Ascomycota), а також представники базідіоміцетових грибів (Basidiomycota) і псевдогрибів (Oomycota). Зокрема, до переліку лідерів за показником річного спорового індексу входили спори Alternaria, Ascospora, Cladosporium, Coprinus, Didymella, Epicoccum, Ganoderma, Leptosphaeria, спори порядків Uredinales та Ustilaginales.

Найбільше СГ реєструвалося в атмосферному повітрі у період 3 червня по жовтень 3 чітко окресленими підйомами концентрації, в основному за рахунок спор Cladosporium у червні і липні. Також пік у липні мали Alternaria і Ascospores. B осінні місяці спостерігалася вища концентрація спор у повітрі, ніж у весняні місяці і у першу половину червня.

Дані за контентом спор грибів в атмосферному повітрі для тривалого періоду спостереження отримано для України вперше. Результат дозволить поліпшити діагностику і профілактику сезонної алергії у нашій країні.

\section{ЛІТЕРАТУРА}

1. Breitenbach M., Crameri R., Lehrer S.B. Fungal Allergy and Pathogenicity. A timely overview of molecular and clinical aspects. Chemical Immunology. 2002. Vol. 81. 310 p.

2. Fröhlich-Nowoisky J.,

Pickersgill D.A., Desprès V.R., Pöschl U. High diversity of fungi in air particulate matter. Proceedings of the National Academy of Sciences of the United States of America. 2009. № 106 (31). P. 12814-12819.

3. Cole G.T., Hoch H.C.

The Fungal Spore and Disease Initiation in Plants and Animals. New-York : Springer Science+ Business Media, 1991. 554 p.

4. Desprès V.R., Nowoisky J.F., Klose M., Conrad R., Andreae M.O., Pöschl U. Characterization of primary biogenic aerosol particles in urban, rural, and high alpine air by DNA sequence and restriction fragment analysis of ribosomal RNA genes. Biogeosciences. 2007. № 4

P. 1127-1141.

5. Wu Z., Tsumura Y.,

Blomquist G., Wang X.-R.

$18 \mathrm{~S}$ rRN Agene variation among common air borne fungi, and development of specific oligonucleotide probes for the detection of fungalisolates. Applied and Environmental Microbiology. 2003. № 69. P. 5389-5397.

6. Simon-Nobbe B., Denk U., Pöll V., RidR., Breitenbach M. The Spectrum of Fungal llergy. Int Arch Allergy Immunol. 2008. № 145. P. 58-86

7. Burge H.A. Fungus allergens. Clinical Reviews in Allergy. 1985. Vol. 3. Issue 3.

\section{P. 319-329}

8. Гришило П.В. Алергенспецифічна імунотерапія: стандартні підходи та сучасні погляди. Клінічна імунологія. Алергологія. Інфектологія. 2011. № 6/7. C. 25-28.

9. Пухлик Б.М. Ситуация с аллергическими заболеваниями и аллергологией в Украине. Клінічна імунологія.

Алергологія. Інфектологія. 2013. № 2. С. 7-9. 
10. Black P.N., Udy A.A., Brodie S.M. Sensitivity tof ungal allergens is a risk factor for lifethreatening asthma. Allergy. 2000. Vol. 55. Issue 5. P. 501-504.

11. Sofiev M., Bergmann K.-C. Allergenic Pollen: A Review of the Production Release, Distribution and Health Impacts. Dordrecht : Springer Science+ Business Media, 2013. 252 p.

12. O'Connor D.J., Sadyś M., Skjoth C.A., Healy D.A.,

Kennedy R., Sodeau J.R.

Atmospheric concentrations of

Alternaria, Cladosporium,

Ganoderma and Didymella

spores monitored in Cork

(Ireland) and Worcester

(England) during the summer of

2010. Aerobiologia. 2014. № 30

(4). P. 397-411.

13. Horner W.E., Helbling A.,

Salvaggio J.E., Lehrer S.B.

Fungal allergens. Clin. Microbiol. Rev. 1995. Vol. 8. №2.

P. 161-179.

14. Middleton E.Jr., Reed C.E., Ellis E.F., Adkinson F.N.Jr., Yunginger J.W., Busse W.W. Allergy: Principles and Practice. 5-th ed. Mosby, 1998. 1933 p.

15. Garrett M.H., Rayment P.R., Hooper M.A., Abramson M.J., Hooper B.M. Indoor airborne fungal spores, house dampness and associations with environmental factors and respiratory health in children. Clinical \& Experimental Allergy. 1998. Vol. 28. Issue 4. P. 459-467.

16. Kasprzyk I., Rodinkova V., Sauliené I., Ritenberga O., Grinn-Gofron A., Nowak M. Sulborska A., Kaczmarek J., Weryszko-Chmielewska E., Bilous E., Jedryczka M. Air pollution by allergenic spores of the genus Alternaria in the air of central and eastern Europe. Environmental Science and Pollution Research. 2015. Vol. 22. Issue 12. P. 9260-9274.

17. Molina R., Manzano J., Rodriguez S. Influence of environmental factors onmeasurements with Hirstsporetraps. Grana. 2013. Vol. 52. Issue 1. P. 59-70.

18. Mozo H.G. Minimum requirements to manage aerobiological monitoring stations included in a national network involved in the EAN.

International Aerobiology

Newsletter. 2011. № 72. P. 1-2.

19. Родінкова В.В. Наукове обґрунтування системи моніторингу та профілактики впливу алергенних чинників біоло- гічного походження на стан здоров'я міського населення України : автореф. дис. ... доктора біол. наук : 14.02.01. К., 2015. 38 c.

20. Sadyś M., Kaczmarek J., Grinn-Gofron A., Rodinkova V., Prikhodko A., Bilous E., Strzelczak A., Herbert R., Jedryczka M. Dew point temperature affects as cospore release of allergenic genus

Leptosphaeria. International Journal of Biometeorology. 2018. URL : https://doi.org/10. 1007/s00484-018-1500-z

21. Weber R.W. Allergen of the Month - Stemphylium. Annals of Allergy, Asthma and Immunology. 2015. Vol. 114. Issue 1. P. A11.

22. Panjabi C., Shah A. Allergic Aspergillus sinusitis and its association with allergic broncho pulmonary aspergillosis. Asia Pacific Allergy. 2011. № 1 (3). P. 130-137.

\section{REFERENCES}

1. Breitenbach M., Crameri R. and Lehrer S.B. Chemical Immunology. 2002 ; 81 : $310 \mathrm{p}$.

2. Fröhlich-Nowoisky J., Pickersgill D.A., Desprès V.R. and Pöschl U. Proceedings of the National Academy of Sciences of the United States of America. 2009 ; 106 (31) :

12814-12819.

3. Cole G.T. and Hoch H.C.

The Fungal Spore and Disease Initiation in Plants and Animals.

New York : Springer

Science+Business Media ; 1991 : $554 \mathrm{p}$.

4. Desprès V.R., Nowoisky J.F., Klose M., Conrad R., Andreae M.O. and Pöschl U. Biogeosciences. 2007 ; 4 : 1127-1141.

5. Wu Z., Tsumura Y., Blomquist G. and Wang X.-R Applied and Environmental Microbiology. 2003 ; 69 : 53895397.

6. Simon-Nobbe B., Denk U., Pöll V., Rid R. and Breitenbach M. Int Arch Allergy Immunol. 2008 ; 145 : 58-86.

7. Burge H.A. Clinical Reviews in Allergy. 1985 ; 33 :

319-329.

8. Hryshylo P.V. Klinichna imunolohiia. Alerholohiia. Infektolohiia. 2011 ; 6/7 : 25-28 (in Ukrainian).

9. Pukhlyk B.M. Klinichna imunolohiia. Alerholohiia. Infektolohiia. 2013 ; 2 : 7-9 (in Russian).
10. Black P.N., Udy A.A. and Brodie S.M. Allergy. 2000 ; 55 (5). P. 501-504.

11. Sofiev M. and Bergmann

K.-C. Allergenic Pollen: A Review of the Production Release,

Distribution and Health Impacts.

Dordrecht : Springer

Science+Business Media; 2013 : 252 p.

12. O'Connor D.J., Sadyś M., Skjoth C.A., Healy D.A.

Kennedy R. and Sodeau J.R.

Aerobiologia. 2014 ; 30 (4) :

397-411.

13. Horner W.E., Helbling A.,

Salvaggio J.E. and Lehrer S.B.

Clin. Microbiol. Rev. 1995 ; 8 (2)

: 161-179.

14. Middleton E.Jr., Reed C.E., Ellis E.F., Adkinson F.N.Jr.

Yunginger J.W. and Busse W.W. Allergy: Principles and Practice. 5-th ed. Mosby,1998 : 1933 p.

15. Garrett M.H., Ray-

ment P.R., Hooper M.A., Abramson M.J. and Hooper B.M.

Clinical \& Experimental Allergy. 1998 ; 28 (4) : 459-467.

16. Kasprzyk I., Rodinkova V., Sauliené I., Ritenberga O., Grinn-Gofron A., Nowak M., Sulborska A., Kaczmarek J., Weryszko-Chmielewska E., Bilous E. and Jedryczka M. Environmental Science and Pollution Research. 2015 ; 22 (12) : 9260-9274.

17. Molina R., Manzano J. and Rodriguez S. Grana. 2013 ; 52 (1) : 59-70.

18. Mozo H.G. International Aerobiology Newsletter. 2011 ; $72: 1-2$

19. Rodinkova V.V. Naukove obhruntuvannia systemy monitorynhu ta profilaktyky vplyvu alerhennykh chynnykiv biolohichnoho pokhodzhennia na stan zdorovia miskoho naselennia Ukrainy : avtoref. dys. ... doktor bioloh nauk. Kyiv, 2015 : 388 p.

(in Ukrainian).

20. Sadyś M., Kaczmarek J., Grinn-Gofron A., Rodinkova V., Prikhodko A., Bilous E. Strzelczak A., Herbert R. and Jedryczka M. International Journal of Biometeorology. 2018. URL : https://doi.org/10. 1007/s00484-018-1500-z

21. Weber R.W. Annals of Allergy, Asthma and Immunology. 2015 ; 114 (1) : A11.

22. Panjabi C. and Shah $A$. Asia Pacific Allergy. $2011 ; 1$ (3) : 130-137.

Надійшло до редакції 17.01.2018 